\title{
ARCHITECTURAL CRITICISM IN LITHUANIAN INTERWAR PRESS: PRECONDITIONS OF THE PHENOMENON
}

\begin{abstract}
Summary. The main goal of the article is to find out whether a specific genre of architectural criticism was formed in the public discourse of interwar Lithuania (1918-1940), and if so, to define the main tendencies of this phenomenon. After defining the critique of architecture as a public discourse in which, based on theoretical knowledge, reflections on the essence of architecture or evaluations of ongoing urban development and buildings are popularly presented, the article discusses such texts in interwar Lithuania. The publication will acquaint readers with the most creative reviewers of architecture and the thematic variety of publications attributed to architectural critics. The article will also reveal personalised, unexpected assessments of buildings that have already become objects of heritage.
\end{abstract}

Keywords: architectural criticism, modernism, national style, interwar press, interwar Lithuania.

\section{INTRODUCTION}

Architectural criticism can be understood in a broad sense as a wide set of possibilities for shaping public opinion. Many processes, such as activism initiatives, artistic interpretations or even spontaneouslydeveloping discourse on social media, can potentially influence the public's perceptions of architectural space. However, one can get the impression that a text of architectural criticism in Lithuania is not a frequent phenomenon as there is a lack of publications, authors and various approaches. Is this assumption correct? Is architectural criticism in Lithuania experiencing a decline? Or is it, on the contrary, transforming and acquiring other forms? When considering these relevant questions, it is useful to get acquainted with the history of the phenomenon in an attempt to grasp the beginnings of Lithuanian architectural criticism.

Criticism as a phenomenon of architectural culture has not been widely studied in the works of Lithuanian architectural historians. It can be assumed that this reflects a general tendency not to distinguish critical discourse on architecture oriented towards a broad audience as a fully-formed phenomenon, but to speak about it in the general context of art study. ${ }^{1}$ This is especially particularly characteristic of the discourse of the first half of the $20^{\text {th }}$ century. Speaking about the origins of this phenomenon in Lithuania, architectural theorist Almantas Samalavičius even suggests that "in independent Lithuania, architectural traditions were just beginning to be established, and criticism lagged far behind the development of architectural art". Thus, the main aim of this study is to find out whether a specific genre of architectural criticism emerged in the public discourse of interwar Lithuania, and if so, to define the main tendencies of this phenomenon.

Having set out the aim to carry out a historical study of the genre of criticism, it is necessary to first define the term itself. In the $19^{\text {th }}$ century, with the emergence of architectural criticism as a specific way of communicating about architecture, the founding principles of criticism were also identified, namely the writer's desire to reflect and to actively change architectural processes as well as write texts not only for professionals but also for the general public. In 1837, in his book Elements of Architectural Criticism, Joseph Gwilt set the goal of instructing not only professors but also the general public in matters of architectural taste. ${ }^{3}$ Harold Desbrowe Annear, an architect from Melbourne, in his lecture entitled Some Methods of Architectural Criticism delivered at 
the Royal Victorian Institute of Architects in 1893, not only noted the public's lack of interest in, and knowledge of, architectural matters but also presented criticism as a weapon to protect the public from poor quality buildings. ${ }^{4}$

Based on these classical outlines, criticism in this paper will be interpreted as a theoretically engaged, but wide-audience-oriented, discourse on architecture. From this position, we will try to assess the public knowledge about architectural processes and answer the question of whether there are preconditions for looking for the origins of Lithuanian architectural criticism in the interwar press. Therefore, the objectives of the article are to identify the scope and tendencies of public writing, identify whether public architectural discourse has elements of architectural criticism, and to recap these texts into key thematic groups.

Although there was no comprehensive theoretical analysis of the relationship between the society and architecture in interwar Lithuania, it is obvious we cannot look for a conscious contemporary understanding that "architectural experience and perception are always inevitably mediated by language and discourse." ${ }^{5}$ Nevertheless, discussions about architecture were an important part of the culture of the time. In the Lithuanian context, texts about architecture intended for a wide public were published in the cultural (Naujoji Romuva, Kultūra, Židinys and other), professional (Statybos menas ir technika, Savivaldybé, Technika ir ükis and other) and broad-audience-oriented (Lietuvos žinios, Bangos, $X X$ amžius and other) press. Despite the fact that none of these publications can be directly linked to architecture (the main architectural magazines read in Lithuania until 1940 included those published abroad, e.g., Moderne Bauformen, Baukunst, Der Baumeister, Larchitecture d'aujourd'hui), ${ }^{6}$ the article will examine some of those publications as having the characteristics of architectural criticism.

In terms of the thematic approach to public architectural discourse, the study is based on three main blocks. Firstly, there are the texts that can be generalised as an attempt to define the essence of architecture. General laws and trends of architecture are analysed and presented to a wide audience, including issues of national architectural style, reflections on the modern world in an architectural context, discussions of individual architectural ideas, such as the urban garden and so on. Another group of texts deals with the coverage of specific urban processes. This is a broad group of publications which reacts sharply to the problems of urban hygiene, analyses situations of urban management, urban planning manifestations, etc. The third group of texts deals with the discussion of a specific object or a project. In this study, we will briefly look at each of these groups.

\section{ON ESSENCE OF ARCHITECTURE: FINDING A BENCHMARK}

In a classic definition of criticism, Krescensijus Štoškus claimed that "criticism can exist as a public theorised perspective on emerging artistic phenomena and new tendencies"? In interwar Lithuania, this tendency is most often related to public attempts made by architects to define the aims and essence of architecture. One of the earliest attempts of this type was made by Vladimiras Dubeneckis in the cultural journal Baras in 1925. In his publication, Dubeneckis tried to draw attention to the idea that the essence of architecture is not by far only related to its functions but inevitably to the expression of cultural preferences of the society. $\mathrm{He}$ wrote that "architecture presents the path of will in an epoch, teaches to predict the future and even create new directions in life". ${ }^{8}$ The publication was intended for a wide audience as it was written in an easily understood language for that time. Nevertheless, the author also included a professional message on the ethical significance of architecture.

Wayne Attoe relates such a tendency of public discourse to the genre of normative criticism. It is a public discourse that develops a belief that "somewhere in the world, outside a building or urban setting there is a model, pattern, standard or principle against which its quality or success may be assessed". This criticism is inseparable from the benchmark, which is often aesthetic-stylistic, and from attempt to present an evaluation system based on such a benchmark. The search for a benchmark 
is also based on the classical theory of architecture, the foundations of which were laid in the Western context by Vitruvius. He not only wrote about the principles of composition but, by relying on the concept of eurythmy, analysed a topic close to criticism, namely the sight of beauty as something which "appears to be so" in the process of interaction between the observer and the building. ${ }^{10}$ The classical architectural criticism theory also relies on the principle of a benchmark. Joseph Gwilt's book Elements of Architectural Criticism relates to the theory of architecture. It presents classical principles of proportions as well as Greek, Italian and German architecture schools. ${ }^{11}$ Thus, instead of focusing on uniqueness, normative criticism seeks expressions of generality.

The normative aspect is very clearly recognisable in the architectural discourse of interwar Lithuania. Although a separate study would be necessary in order to fully define the variety of theoretical statements and ethical approaches developed by different authors, it is clear that the most widely discussed normative systems were based on an attempt to define architectural modernity and, at the same time, search for the national character and the authenticity of a place. The texts analysing these themes share many other characteristics of criticism; they present arguments based on tangible theoretical concepts and expressed in a popular language that everyone can understand. In this field, one can clearly notice individual judgements expressed not only from the architect's point of view but also from different professional or official positions.

There is a tendency for architects to remain quite restrained, using a discourse close to theory even when speaking in public. This can be demonstrated by a characteristic public quote about the definition of modernism given by engineer Karolis Reisonas who said "It would be a sin not to make use of machines as they make it possible to improve the construction of flats in all countries and make it cheaper. Due to this reason, the forms used are limited to those which can be forged by means of machines." This is a clear reference to a machine à habiter ("machine for living"), which was one of the most widely used metaphor of modern architectural theory. In the same article, Reisonas continues: "ornaments should be replaced by a combination of different materials. By denying external decoration, which in the old architecture often concealed poor proportions of different parts, the new architecture demands good proportions". ${ }^{2}$ With such an argument Reisonas interprets Adolf Loos's statement that "evolution of culture comes to the same thing as removal of ornament from functional objects." 13

Texts of normative nature form a significant part of the creative legacy in the works of Vladas Švipas, Vytautas Žemkalnis Landsbergis, Feliksas Bilielinskis, Jonas Kovalskis-Kova, Jurgis Getneris or even Mykolas Songaila and many other architects and engineers. An exemplar case is a strong and emotionally suggestive statement by architect Feliksas Bielinskis, who claims that "an architect has as much right to build a self-centered building as he has to stand on the street and hand out slaps to passers-by." ${ }^{14}$ Such call for contextualism clearly refers to one of the idioms of modern language of architecture where building should demonstrate "close relationship with the urban environment". ${ }^{15}$ Or, on the contrary, architect Mykolas Songaila develops a normative argument about the role of public architecture as a tool "to introduce classical forms" 16 This was an argument to explain a newly built faculty of chemistry and physics (Fig. 1).

Representatives of other professions and anonymous authors using pseudonyms speak much more freely about the essence of architecture. Very playful texts promoting modernity were published in

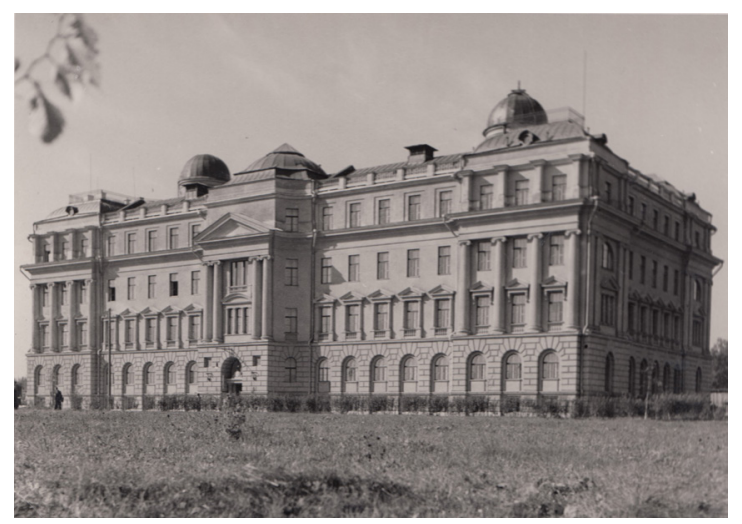

Fig. 1. Faculty of Chemistry and Physics of Vytautas Magnus University, architect Mykolas Songaila, 1931, from the Library of Kaunas University of Technology 
the journal Bangos: "Innovations promoted and introduced in the furnishing of flats are not by any means machine guns aimed at our comfort and good customs. On the contrary, they give people the maximum comfort and other benefits." ${ }^{\prime 17}$ This particular text, and many other similar discussions, illustrates the perception of the concepts of Existenzminimum, standardisation and rationalisation which, according to Walter Gropius, is an "expression of life of our epoch in clear and crisply simplified forms."18

Brigadier General Juozas Barzda-Bradauskas's statement about the principles of modern architecture published in 1933 in Mūsǔ žinynas is also worthy of mention: "The modernists, with rationality first and foremost in mind, do not abandon aesthetics, but strive for beauty by new means; their basic forms are combinations of cones, but these combinations are given a 'figure', a kind of spatial rhythm, sometimes even a dynamic expression (the house seems to move, the stairs rise up, the openings are inviting); such houses often look really interesting and beautiful, and sometimes even turn into a real spatial symphony". ${ }^{19}$ Although the article is intended to shed light on the issues of modernisation of barracks (Fig. 2), the rhetoric of the text is yet another great example of the choice of statements for architectural argumentation that correspond to the dominant clichés of modernist architectural theory. BarzdaBradauskas in his writing about modern aesthetics in a way continues Walter's Curt's Behrendt's understanding the mission of modernism as a "complete spiritual revolution in building".20

Texts about the goals of architecture included some critical judgments. The fiercest debate was over

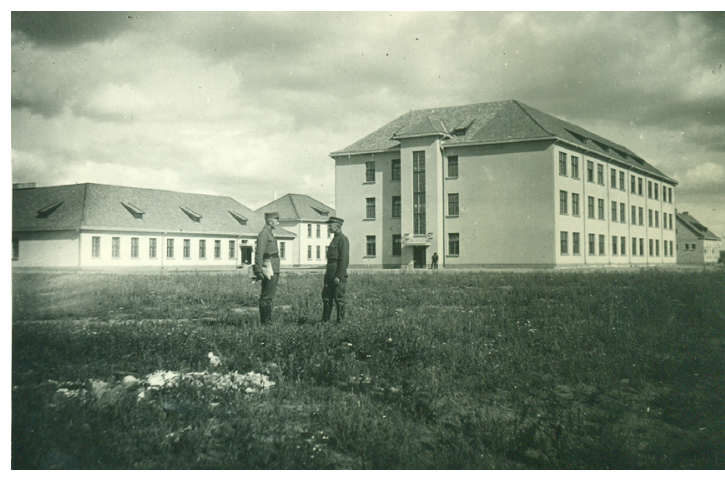

Fig. 2. Military barracks in Kupiškis, built in 1936, from the Archive of Kupiškis Ethnographic Museum the national style. The political order of this style is illustrated by the public speeches of President Antanas Smetona himself. In 1937, he wrote in the professional journal Technika ir ükis: "Isn't the socalled modernism brought by our engineers from Italy and other western countries taking root? And yet we admire and are proud of our Lithuanian heritage - our huts, crosses and chapels. Why aren't our architects creating Lithuanian style? There seems to be no shortage of material. I hope we will not lose Lithuanian spirit by trying to modernise it!" ${ }^{21}$ However, the political position does not withhold criticism. For example, Mstislavas Dobužinskis boldly claims that "this misery that is currently presumably considered to be Lithuanian style will stay in our history not even as an odd thing but as a disgusting 'Kinderkrankheit', which is 1920-40 style"22 (Fig. 3). Various kinds of criticism of the national style were expressed by a number of other authors, including Michailas Vorobjovas, Algirdas Šalkauskis, Jonas Kovalskis-Kova and others.

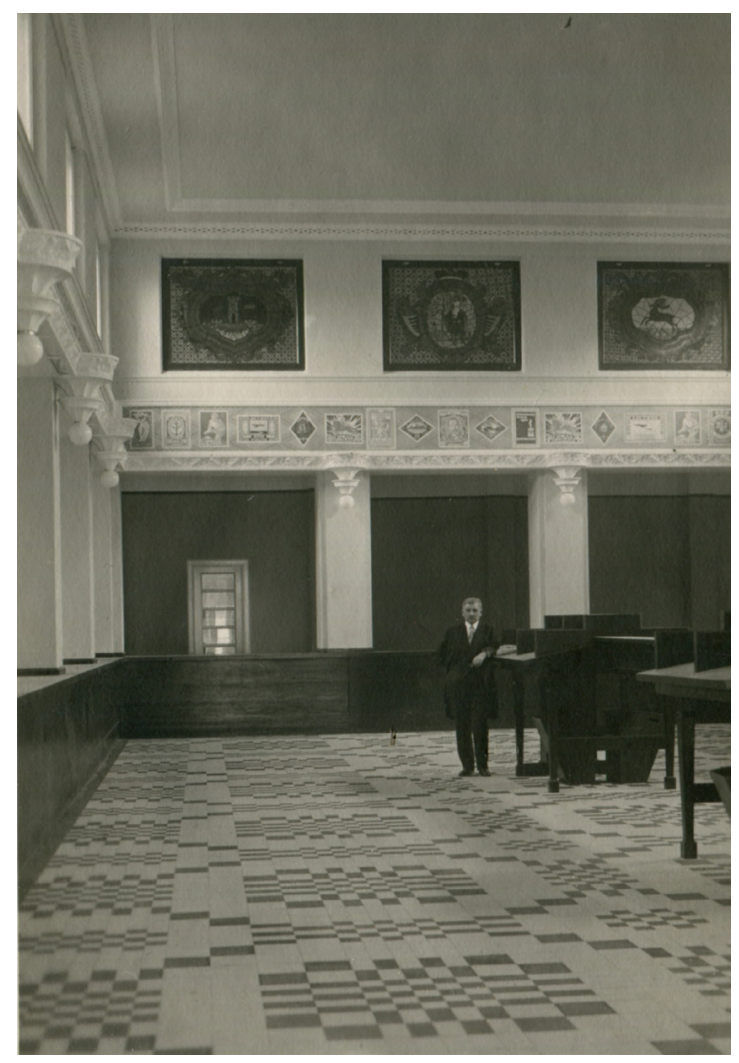

Fig. 3. Interior of Kaunas Central Post Office with building architect Feliksas Vizbaras, built in 1930, from the personal collection of Antanas Burkus 


\section{CRITICAL REFLECTION ON URBAN DEVELOPMENT}

Adam Sharr, an architecture theorist, notes that "physical spaces are, at least in part, set out by social and political configurations". ${ }^{23}$ This relates to one of the fundamental tasks of architectural criticism, namely to perceive, comment on and influence the social urban atmosphere. The role of the writer here "is more active: he or she is called upon to judge a much wider slice of the urban environment, and his or her words have the potential to change the shape and growth of the city". ${ }^{24}$ In today's context, texts of this kind could be seen as urban activism. Nevertheless, in the press of interwar Lithuania, there are also statements that indicate a clear awareness of the importance of public opinion in shaping cities. For example, Jurgis Getneris, who was active in writing on urban issues, stressed that "the appearance of a city does not depend solely on urban planners or engineers; the greatest obstacles to the rational and aesthetic development of the city are probably the backward and uncultured society". ${ }^{25}$ Such a growth of architectural culture is hardly possible without a public debate on topics that deal with issues of public interest in urban development.

Summarising the architectural information presented in the newspapers and magazines of interwar Lithuania, it can be said that one of the most solid thematic blocks is the articles on urban planning processes. Urban reflections cover a very wide range of urban issues: information provided by municipalities about planned and ongoing urban development works, opinions and proposed visions of the future by politicians and officials, fragments of urban history, or even theoretical discourse on urban planning as a discipline. Not all of these publications can be classified as architectural criticism. Some of them are reports, and some can even be described as works of architectural history or theory. However, there is also discourse that has a critical purpose in supporting "our understanding of the physical environment and efforts to improve its usefulness and quality". ${ }^{26}$

One of the most important aims of architecture is social impact. According to Steponas Stulginskis, promoter of modern architecture, social character of building has a huge impact on the nation and, therefore, it is not good to give all building business to the private initiative. ${ }^{27}$ Social problems have been explored by many specialists, including those interested in urban and architectural processes. One of the best examples is criticism against unnecessary luxury of the Bank of Lithuania in Lietuvos aidas: "During the biggest credit crunch, the Bank of Lithuania built itself a home that even the German Reichsbank can envy". ${ }^{28}$ As it can be seen from the report of the Chief Building Inspector, Antanas Novickis, written to the Minister of the Interior, the issue was also discussed in the regional centres: "The public clearly has negative attitude towards such an expensive and ornate construction. Farmers will be shy to enter the white marble palace". ${ }^{29}$

Cheap housing is an equally relevant architectural topic of a social nature. The press is abundant with reports addressing thorny issues of housing. The popular phrase "housing crisis" is revealed from various perspectives. In 1937, Lietuvos žinios wrote: "The sanitary conditions in Kaunas are simply intolerable. There are about 3,000 yard guards in Kaunas, most of whom live in inhuman conditions" ${ }^{30} \mathrm{XX}$ amžius provided an even more detailed description of the situation: "Most houses have yard guards, but 85\% of them live in terribly damp, dark, concrete, windowless, stinking cellars, wooden warehouses and very often near public latrines". ${ }^{31}$ Nevertheless, this kind of information is close to the genre of the report, it refers to problems of hygiene and cleanliness which was major concern of social reformers and architects of the time. ${ }^{32}$

One the other hand, public writing on this issue also suggests architectural solutions proposed by the experts fit the definition of change-oriented architectural criticism. An excellent example of this is Stulginskis's publication in which he questions the widespread urban beautification measure of "slum demolition": "Slum demolition is not going to create new values. By demolishing slums, we have to provide people left behind with new, good, healthy, cheap flats; we have to build colonies of cheap flats.". S. Stuginskis in his writings develops an argument of modernism as a socialist project where "worker's 
housing has become the key challenge for modern architecture", ${ }^{34}$ as if to follow words of the Russian avant-garde writer Moisei Ginzburg.

Reactions to the prevailing stylistic chaos, uncontrolled nature of construction, lack of hygiene, and illogicality of planning and site selection form an important part of the narratives about cities, which is close to the genre of criticism. The subjective, yet colourful, picture of the city's problems was undoubtedly intended to draw public attention to negative phenomena. For example, in 1932, Lietuvos aidas wrote: "If you enter even a slightly larger provincial town, you will immediately see, even in the very centre, roofs that are rotten, windows that are stuffed with rags, gates and fences that have fallen down, crooked shop signs, icy and covered in snow pavements in the winter, clumps of grease on the streets, pots lined up on the streets, wagons parked on the streets and so on and so forth"35 (Fig. 4). The numerous statements of this kind about the state of cities can be seen as a kind of social catalyst, and at the same time, it can be considered as another group of publications where we can trace the origins of Lithuanian architectural criticism.

\section{PROBLEMS OF AESTHETIC EXPRESSION IN ARCHITECTURE}

In the interwar press, most of the texts about individual buildings are informative and close to the style of the report. For example, in 1934, Lietuvos aidas reported that the Vytautas the Great Gymnasium was being newly built in Klaipeda. The text gave brief information about the most important constructions in Klaipeda, about the planned premises of the

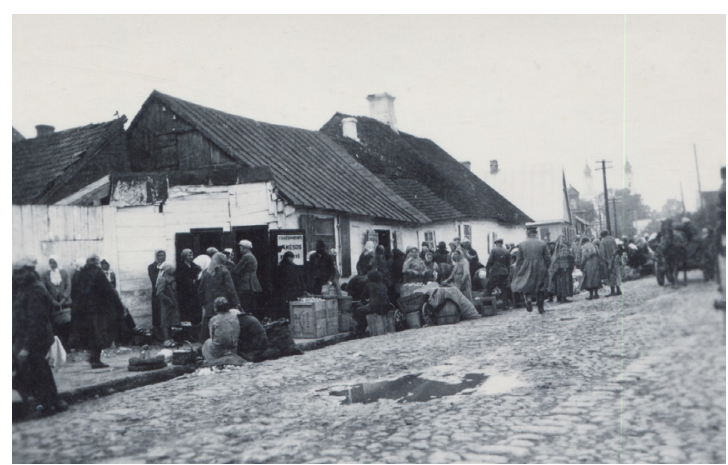

Fig. 4. Streetscape in Marijampole, dates back to about 1938, from the personal collection of Mantas Vaitiekūnas gymnasium, and gave only a brief assessment that "this palace will be the most modern building in the whole are of the Baltic States". ${ }^{36}$ These are descriptive publications, which primarily present facts by using the classic "who, what, where, when and why" formula. They do not reveal in-depth research leading to critical reflection on a phenomenon or an object, nor do they present a personal viewpoint. Although these texts are a valuable source of testimony about architectural processes, they can hardly be associated with critical discourse.

However, public discourse is also marked by critical assessments of individual objects. One of the most widely known stories is the public debate initiated by Halina Kairiukštytè-Jacinienè over the first design of the Church of the Resurrection (Fig. 5). The author writes: "This church looks strange and old-fashioned in the pseudo-Gothic and 'Lithuanian' (?) style <...>. The impression it gives is that we, Lithuanians, are still lagging behind Western Europe as if we still live in the 19th century, which

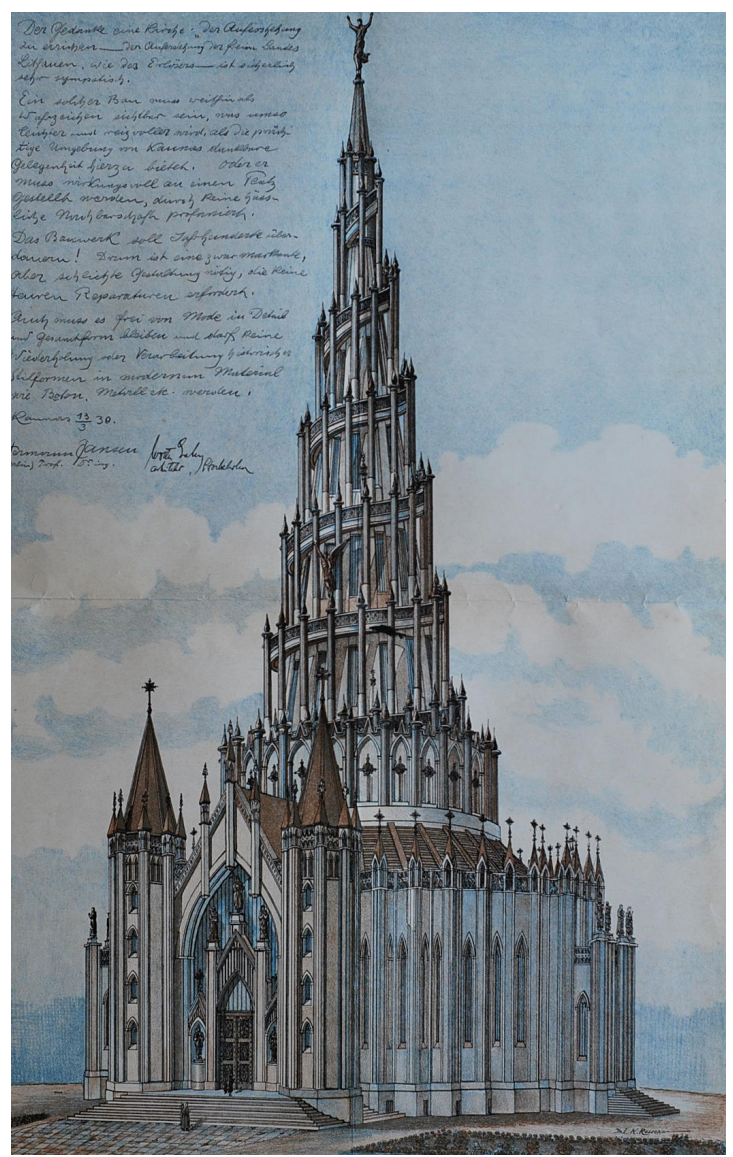

Fig. 5. Preliminary project of Kaunas Church of the Resurrection of Jesus Christ, architect Karolis Reisonas, 1929, from the personal collection of Vaidas Petrulis 
did not have the power to create its own style $<\ldots>$. It must also be assumed that the Church of the Resurrection, built in its present form, will always be very different from low modest houses and cottages on the green hill near the church because they are of a completely different type of construction and do not harmonise with the church". ${ }^{37}$

It is interesting that the public discussion between Halina Kairiūkštytė-Jacinienè and Vytautas Bičiūnas in Lietuvos aidas was commented on by the editorial board of the newspaper. A footnote was added to one of the texts, assuring that "this church is not only of interest to our architects, artists, the clergy and episcopate but also to the general public". ${ }^{38}$ Balys Sruoga, ${ }^{39}$ Adomas Jakštas, ${ }^{40}$ Stasys Laucius ${ }^{41}$ and other authors also discussed the aesthetic form of the church. Thus, this is one of the most obvious examples of architectural criticism addressing the general public. Apart from the fact that the subsequent redesigning of the church project was linked to financial and technical possibilities, the critical discussions can also be seen as a kind of inspiration for change.

Criticism of the Resurrection church project reflects a broader discussion on the ornament decorativeness in modern architecture. Despite the evident feeling that the past is different from the present, hence the architecture of at the beginning the twentieth century should be quite different from the previous centuries, a large part of the architectural aesthetic was still perceived traditionally. Some public writings on architecture openly question the ascetic forms of modernism: "Can one create a style where the spirit have been replaced only by reason?" ${ }^{42}$ This position evident in a large number of significant objects of public buildings: the Bank of Lithuania, the Ministry of Justice, the building for the organisation "Neo-Lithuania" and many others. On the other hand, intellectuals such as historian and art critic Mikalojus Vorobjovas, understood this attitude as dangerous: "Similar stylistic explorations would not even have ever occurred if architecture had not been afflicted by a chronic disease. The main symptom of this disease is the endless love of the facade, both literally and in a broader sense - an excessive admiration for the external appearance". ${ }^{43}$

Despite the existing public controversy, in most cases, the articles in the press have not influenced the actual architectural processes or the aesthetic form of the objects. For example, KairiukštytèJaciniene viewed the project of Vytautas Magnus War Museum (Fig. 6) as unfavourably as the pompous project of the Church of the Resurrection:

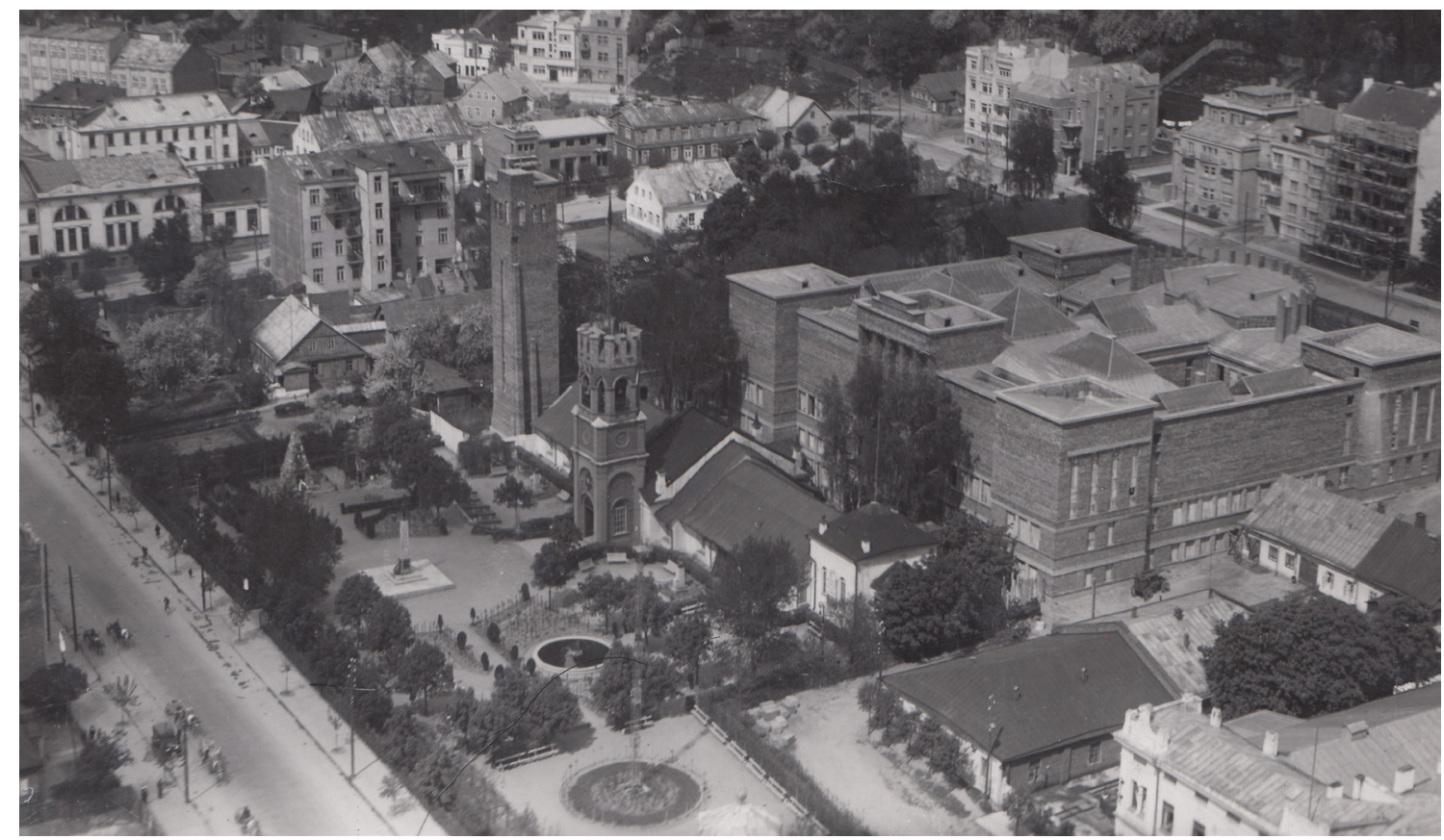

Fig. 6. Construction of Vytautas the Great War Museum and M. K. Čiurlionis National Museum of Art, architect Vladimiras Dubeneckis, built in 1936, from the Library of Kaunas University of Technology 
"I would say that it gives a strange impression of how inharmoniously the floors of both museums have been formed. While the lower floor is heavily fragmented and pierced by rows of windows, which basically reminds of a greenhouse, the upper floor, on the contrary, displays almost completely empty, flat and gloomy areas similar to the walls of a prison or a fortress. One could say, there are no windows at all - just wall planes". ${ }^{44}$ Not all the professionals liked the design of the garden in the War Museum territory either. In 1938, Jurgis Getneris, a representative of younger generation architects, wrote in Naujoji Romuva: "A monument is not a broom. It cannot be placed anywhere where there is an empty space, as it was done in the War Museum".45 Such reactions can be viewed not only as passive reflections but also as an active effort to shape the architectural awareness of society.

Texts dealing with controversial issues related to different objects were abundant in the press. The design of the Jesuit College, designed by E. Peyris, was criticised for its "compromising appearance". 46 The Bank Palace in Kaunas and other bank buildings in different Lithuanian cities were described as out of contrast with the surrounding area by being too expensive and decorative. The prevailing tendency to decorate buildings with towers was also criticised. ${ }^{47}$ A great deal of criticism was aimed at the buildings of the national style, e.g. the Central Kaunas Post Office, Pažanga Palace and others. The Sports Hall was called a loser, ${ }^{48}$ and the gymnasium in Šančiai was dubbed "a castle with difficult access for enemies"49 (Fig. 7). It is interesting that many of these comments were signed by the authors' real names, not under pseudonyms as was popular at the time. In fact, the editor of Naujoji Romuva had to issue an apology to the Head of the Press and Education Division of the Military Staff for publishing Jurgis Generis's criticism of the garden in the area of the War Museum. The editor apologised by stating the following: "His thoughts were only referred to me on the telephone" and "the comment was inadvertently included".50 The architect himself had to apologise as well.

From a contemporary perspective, these reactions to buildings provide an opportunity to look at the canonical objects of architectural heritage from a different perspective. Here, it is useful to recall the

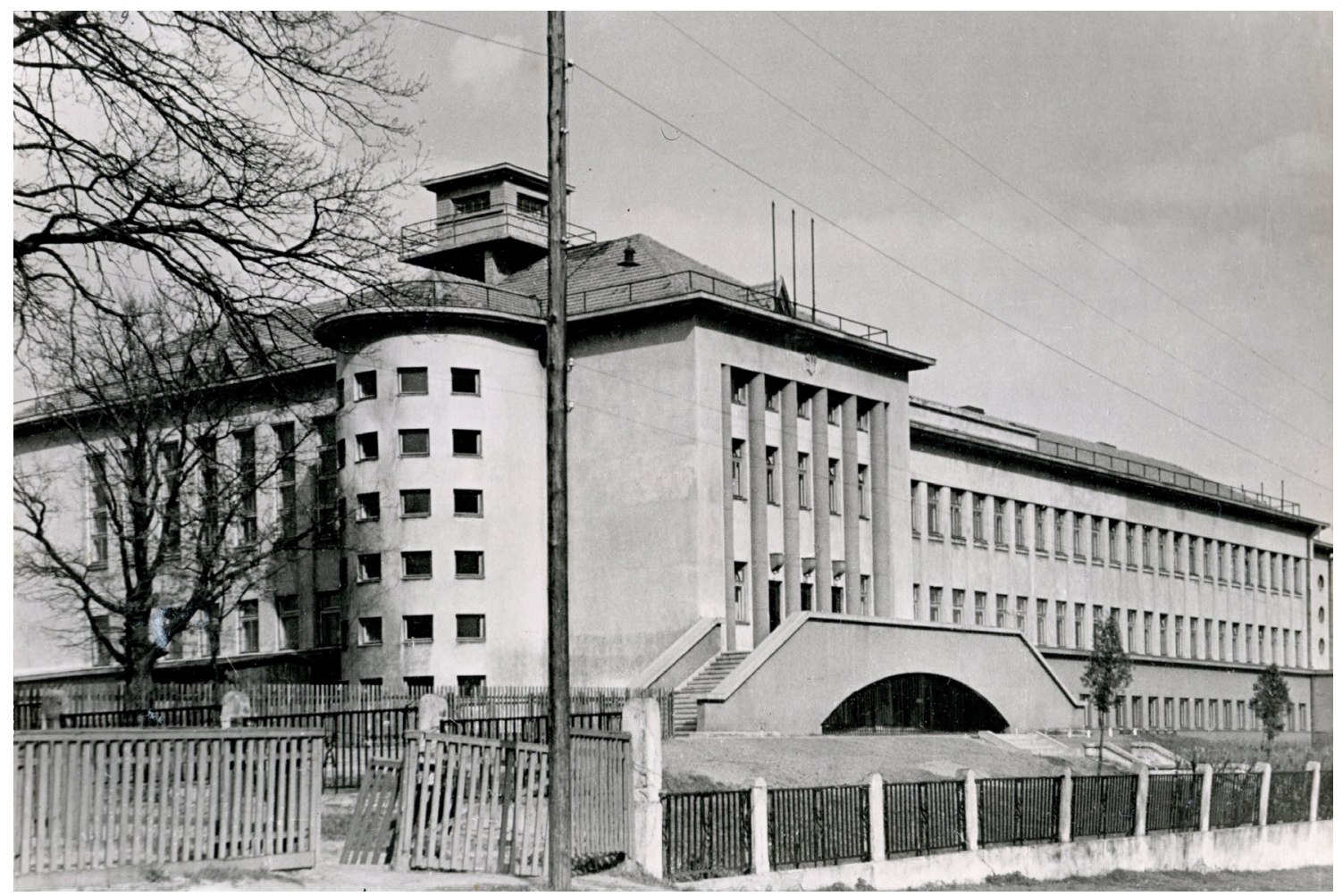

Fig. 7. Gymnasium in Šančiai, architect Stasys Kudokas, built in 1939, from the Archive of Institute of Architecture and Construction of Kaunas University of Technology 
remark made by Blair Kamin, an American architectural critic, who said that "critics write the first draft of architectural history". ${ }^{51}$ The ability to react openly and critically to the ongoing processes is undoubtedly one of the most important testimonies to the fact that architectural criticism was a valuable part of the architectural discourse in interwar Lithuania. Such discussions created an intellectual field in which the canon of interwar architecture in Lithuania was formed.

\section{CONCLUSION}

A brief overview of the polemic texts on architecture and urban development published in the interwar press shows that the press of that time had the characteristics of architectural criticism. First of all, the texts reveal an obvious purpose to influence architectural processes. Theoretically-grounded texts raising professional questions were published in a widely read press, written in a language that was easily understood to the public and was quite emotional. There were a lot of authors involved in the process of writing, which shows the deep involvement and literacy of the public. Writer Ignas Šeinius, pedagogue Juozas Vokietaitis, Brigadier General Juozas Barzda-Bradauskas and many other writers participated in polemics on architectural topics. Thus, although in comparison with the avant-garde centres of the formation of modernism in Lithuania, the position of the writers lacked radicalism and a deeper cultural context when assessing the diversity of architectural thought, one can observe that the texts close to architectural criticism were significant tools used for the architectural education of society.

The classical aim of architectural criticism to give a benchmark for the good taste in architecture in the Lithuanian interwar press mainly focuses on the effort to draw the line between the international agenda of the Modern Movement and the demand for a local, or even national, character of architecture. The advocates of modernism use main keywords of the international discourse on new architecture, such as "machine for living", "ornament-less" aesthetics and likewise. The modern discourse was particularly important in presenting the benchmark of the new, modern, hygienic interior. More conservative authors, on the other hand, doubt whether the "American speed" of the modern world may destroy our identity and national character of architecture, and suggest to look for a national motif. These sets of value system also appear in the texts on individual projects and buildings of that time (Church of the Resurrection, Central Post Office, office building for the Pažanga company and others).

Another big group of texts which may be referred to architectural criticism is comments on urban development. Nevertheless, most of the press simply indicates existing problems (such as unpaved city roads, bad smells due to lack of sewerage or similar), some of the writers extensively use modernist criteria such as hygiene, openness, fresh air or social justice. An important aspect of this discussion is the coherence between buildings and the choice of location. These issues are directly related to the themes of aesthetics and urban symbolism and can be considered a critique of architecture.

\section{References}

"Ar atgimsta architektūra? [Is architecture being reborn?]". Židinys [Fireplace] 2 (1935): 636-637.

"Bokštuotasis Kaunas [Kaunas of towers]". Lietuva [Lithuania], 4 January 1928, 4.

"Dar dèl Kauno statybos neplaningumo [More on unplanned construction of Kaunas]“. Naujoji romuva [New romuva] 25-26 (1939): 526-527.

“J. E. Lietuvos Respublikos Prezidentas rašo [His Eminence the President of the Republic of Lithuania writes]“. Technika ir ükis [Technology and economy] 2 (1937): 41-42.

"Kauno kiemsargių balsas visuomenei [The voice of Kaunas guards to the public]“. XX amžius [20th century], 29 January1937, 5.

"Laikraščių iškarpos, kuriose rašoma apie muziejų [Newspaper clippings about the museum]“, 1938. Lithuanian Central State Archives, f. 1764, ap. 1, b. $279,1.3$.

"Miesto tarybos posedis [The meeting of city council]“. Lietuvos žinios [News of Lithuania], 15 January 1937, 7.

"Mintys apie Kauną [Thoughts on Kaunas]". Lietuvos aidas [Echoes of Lithuania], 25 January 1929, 3.

"Naujai statomi Klaipėdos Vytauto Didžiojo gimnazijos rūmai [New construction for Vytautas Magnus Gymnasium in Klaipeda] “. Lietuvos aidas [Echoes of Lithuania], 13 January 1934, 16. 
"Naujoviškas butas [New type of apartment]". Bangos [Waves] 24 (1932): 654.

"Ponui ministeriui raportas [Report to the Minister]“. 13 November 1935. Lithuanian Central State Archives, f. 1622 , ap. 4, b. 509, 1. 1 .

"Susirūpinkime provincijos kultūrinimu [Let's worry about cultivating the province]“. Lietuvos aidas [Echoes of Lithuania], 2 February 1932, 4.

Attoe, Wayne. Architecture and Critical Imagination. Chichester, New York, Brisbane, Toronto: John Wiley \& Sons, 1978.

Barzda-Bradauskas, Juozas. "Moderninè kareivinè [Modern barracks]“. Mūsų žinynas [Our manual] 100 (1933): 71-82.

Behrendt, Walter Curt. Modern Building. Its Nature, Problems, and Forms. New York: Harcourt, Brace and Company, 1937.

Bielinskis, Feliksas. "Mūsų miestų architektūra ir civilizacija [Civilization and architecture of our cities]". In Technika ir ükis [Technology and economy] 6 (1939): 125-126.

Dobužinskis, Mstislavas. "Dar dèl lietuviško stiliaus [More on the Lithuanian style]". Naujoji romuva [New romuva] 37-38 (1938): 698-699.

Dubeneckis, Vladimiras. "Apie mūsų architektūrą [On our architecture]“. Baras [Field] 1 (1925): 89-95.

Getneris, Jurgis. "Architektoninè miestų raida [Architectural development of cities]. Naujoji romuva [New romuva] 35-36 (1938): 675-678.

Getneris, Jurgis. "Kelios urbanistinès gairès „uosto“ kvartalui planuoti [Some urban guidelines for planning a "port" quarter]“. Naujoji Romuva [New romuva] 39 (1938): 715-716.

Ginzburg, Moisei. Style and Epoch, Moscow, 1924. Reprint, London: Fontanka Publications, 2018.

Gropius, Walter. The New Architecture and the Bauhaus. Cambridge: the MIT Press, 1965.

Gwilt, Joseph. Elements of Architectural Criticism, for the Use of Students, Amateurs, and Reviewers. London: John Williams, 1837.

Jakštas, Adomas. "Atviras atsakymas p. B. Sruogai [Open answer to B. Sruoga]". Rytas [The morning], 29 April 1929, 4-5.

Kairiūkštytè-Jacynienè, Halina. "Dèl prisikèlimo bažnyčios projekto [On the project of the Resurrection Church]". Lietuvos aidas [Echoes of Lithuania], 4 November 1929, 5.

"Dèl prisikèlimo bažnyčios [On the Ressurection Church]“. Lietuvos aidas [Echoes of Lithuania], 28 November 1929, 3-4.

—. „Dèl Vytauto Didžiojo vardo muziejaus projekto [On the project for Vytautas Magnus museum]“. In Židinys [Fireplace] 8-9 (1931): 167-170.

Kamin, Blair. "Architecture Criticism: Dead of Alive?" Nieman Reports, July 16, 2015, https://niemanreports. org/articles/architecture-criticism-dead-or-alive/

Kovalskis-Kova, Jonas. "Kauno miesto tvarkymas [On management of Kaunas]". In Naujoji romuva [New romuva] 47 (1937): 875.

Landsbergis, Vytautas. "Urbanizmo klausimas Lietuvoje [On question of Urbanism in Lithuania]“. Naujoji Romuva [New romuva] 4 (1936): 885-889.
Lange, Alexandra. Writing about architecture. Mastering the language of buildings and cities. New York: Princeton architectural press, 2012.

Laucius, S. "Dèl prisikèlimo bažnyčios [On the Ressurection Church]“. Šiaurés Lietuva [Northern Lithuania], 27 June 1930, 2.

Loos, Adolf. Ornament and Crime. Thoughts on Design and Materials. London: Penguin Random House UK, 2019.

Lukšionyte, Nijolè and Aušrinè Kulvietytè-Slavinskienè. "Menotyros publikacijos tarpukario Vilniuje ir Kaune [Publications of art history in interwar Vilnius and Kaunas]“. Art History \& Criticism 7 (2011): 218-232.

Marcus, Thomas A. and Deborah Cameron. The Words Between the Space. London, New York: Routlege, 2002.

McEwen, Indra Kagis. Vitruvius. Writing the body of architecture. Cambridge: MIT Press, 2003.

Overy, Paul. Light, air and openness. Modern architecture between the wars. London: Thames and Hudson, 2007, 49.

Plaat, Deborah van der. "Architectural ignorance and public indifference". Fabrications, 19:1 (2009): 162-175.

Reisonas, Karolis. "Naujos idèjos architektūroje [New ideas in architecture]". Savivaldybe [The municipality] 9 (1933): 35-36.

Samalavičius, Almantas. Architektūros kritika [Criticism of Architecture]. Vilnius: Technika, 2010.

Sharr, Adam. Reading architecture and culture. Researching buildings, spaces and documents. London, New York, Routledge, 2012.

Songaila, Mykolas. "Vytauto Didžiojo Universiteto Fizikos-Chemijos institutas [The faculty of Physics and Chemistry of Vytautas Magnus University]“. Technika [Technology] 7 (1931): 459-498.

Sruoga, Balys. "Atsikèlimo bažnyčios klausimu. Atviras laiškas p. A. Jakštui [On the Resurrection Church. Open letter to A. Jakštas]“. Rytas [The morning], 29 April 1929, 2-3.

Stoškus, Krescencijus. "Meno kritikos paskirtis [The purpose of art criticism]". Meno kritika [Art criticism]. Vilnius, Mintis, 1986, 51-90.

Stulginskis, Steponas. "Kokia turètų būti Lietuvos statybos politika [What should be Lithuania's construction policy]". Savivaldybe [The municipality] 1 (1939): 21-26.

. "Lietuvos statybos politikos gairès gairès [The guidelines of Lithuanian economy of construction]". Technika ir ükis [Technology and economy] 4-6 (1938): 100-108.

Vorobjovas, Michailas. "Architektūros dorovè [The morality of architecture]“. Lietuvos aidas [Echoes of Lithuania], 5 September 1939, 4.

Zevi, Bruno. The Modern Language of Architecture. Seattle and London: University of Washington Press, 1978.

Žalnieraitis, Vytautas. “Lietuviškos „Moderne Bauformen" [Lithuanian „Moderne Bauformen"]". Technika ir ūkis [Technology and economy] 2 (1940): 35-36. 


\section{Notes}

1 Nijolè Lukšionytė, Aušrinė Kulvietytė-Slavinskienè, "Menotyros publikacijos tarpukario Vilniuje ir Kaune [Publications of art history in interwar Vilnius and Kaunas]", Art History \& Criticism 7 (2011), 218-232.

2 Almantas Samalavičius, Architektūros kritika [Criticism of Architecture] (Vilnius: Technika, 2010), 5.

3 Joseph Gwilt, Elements of Architectural Criticism, for the Use of Students, Amateurs, and Reviewers (London: John Williams, 1837), xiii.

4 Deborah van der Plaat, "Architectural ignorance and public indifference“, Fabrications, 19:1 (2009), 164.

5 Thomas A. Marcus and Deborah Cameron, The Words Between the Space (London, New York: Routlege, 2002), 82.

6 Vytautas Žalnieraitis, "Lietuviškos "Moderne Bauformen" [Lithuanian "Moderne Bauformen"]", Technika ir $\bar{u} k i s$ [Technology and economy] 2 (1940), 35-36.

7 Krescencijus Stoškus, „Meno kritikos paskirtis [The purpose of art criticism]", Meno kritika [Art criticism] (Vilnius: Mintis, 1986), 72.

8 Vladimiras Dubeneckis, "Apie mūsų architektūrą [On our architecture]", Baras [Field] 1 (1925), 90.

9 Wayne Attoe, Architecture and Critical Imagination (Chichester, New York, Brisbane, Toronto: John Wiley \& Sons, 1978), 11.

10 Indra Kagis McEwen, Vitruvius. Writing the body of architecture (Cambridge: MIT Press, 2003), 198.

11 Joseph Gwilt, Elements of Architectural Criticism, for the Use of Students, Amateurs, and Reviewers (London: John Williams, 1837).

12 Karolis Reisonas, "Naujos idejos architektūroje [New ideas in architecture]", Savivaldybe [Municipality] 9 (1933), 35.

13 Adolf Loos, Ornament and Crime. Thoughts on Design and Materials (London: Penguin Random House UK, 2019), 188.

14 Feliksas Bielinskis, "Mūsų miestų architektūra ir civilizacija [Civilization and architecture of our cities]", Technika ir ükis [Technology and economy] 6 (1939), 125.

15 Bruno Zevi, The Modern Language of Architecture (Seattle and London: University of Washington Press, 1978), 24.

16 Mykolas Songaila, "Vytauto Didžiojo Universiteto Fizikos-Chemijos institutas [The faculty of Phisichs and Chemistry of Vytautas Magnus University]“, Technika [Technology] 7 (1931), 468.

17 "Naujoviškas butas [New type of apartmeny]", Bangos [Waves] 24 (1932), 654.

18 Walter Gropius, The New Architecture and the Bauhaus (Cambridge: the MIT Press, 1965), 44.

19 Juozas Barzda-Bradauskas, "Moderninè kareivine [Modern barracks]“, Mūsų žinynas [Our manual] 100 (1933), 73.

20 Walter Curt Behrendt, Modern Building. Its Nature, Problems, and Forms (New York: Harcourt, Brace and Company, 1937), 167.

21 "J. E. Lietuvos Respublikos Prezidentas rašo [His Eminence the President of the Republic of Lithuania writes]", Technika ir ükis [Technology and economy] 2 (1937), 42.

22 Dobužinskis, Mstislavas, „Dar dèl lietuviško stiliaus [More on the Lithuanian style]", Naujoji romuva [New romuva] 37-38 (1938), 699.
23 Adam Sharr, Reading architecture and culture. Researching buildings, spaces and documents (London, New York, Routledge, 2012), 3.

24 Alexandra Lange, Writing about architecture. Mastering the language of buildings and cities (New York: Princeton architectural press, 2012), 77.

25 Jurgis Getneris, „Architektoninè miestų raida [Architectural development of cities]“, Naujoji romuva [New romuva], 35-36 (1938), 677.

26 Attoe, 2.

27 Steponas Stulginskis, „Lietuvos statybos politikos gairès gairès [The guidelines of Lithuanian economy of construction]", Technika ir ükis [Technology and economy] 4-6 (1938), 100.

28 "Mintys apie Kauną", Lietuvos aidas (25 January 1929), 3.

29 "Ponui ministeriui raportas [Report to the Minister]", 13 november 1935, 30 Lithuanian Central State Archives, f. 1622 , ap. 4, b. 509, 1. 1.

30 "Miesto tarybos posedis [The meeting of city council]“, Lietuvos žinios [News of Lithuania] (15 January 1937), 7.

31 "Kauno kiemsargių balsas visuomenei [The voice of Kaunas guards to the public]", XX amžius [20th century] (29 January1937), 5.

32 Paul Overy, Light, air and openness. Modern architecture between the wars (London: Thames and Hudson, 2007), 49.

33 Steponas Stulginskis, "Kokia turètų būti Lietuvos statybos politika [What should be Lithuania's construction policy]", Savivaldybe [The municipality] 1 (1939), 21.

34 Moisei Ginzburg, Style and Epoch (Moscow, 1924; reprint, London: Fontanka Publications, 2018), 78.

35 "Susirūpinkime provincijos kultūrinimu [Let's worry about cultivating the province]", Lietuvos aidas [Echoes of Lithuania] (2 February1932), 4.

36 "Naujai statomi Klaipèdos Vytauto Didžiojo gimnazijos rūmai [New construction for Vytautas Magnus Gymnasium in Klaipeda]", Lietuvos aidas [Echoes of Lithuania] (13 January 1934), 16.

37 Halina Kairiūkštytè-Jacynienè, "Dèl prisikèlimo bažnyčios projekto [On the project of the Resurrection Church]", Lietuvos aidas [Echoes of Lithuania] (4 November 1929), 5 .

38 Halina Kairiūkštytė-Jacynienè, "Dèl prisikèlimo bažnyčios [On the Ressurection Church]", Lietuvos aidas [Echoes of Lithuania] (28 November 1929), 4.

39 Balys Sruoga, "Atsikèlimo bažnyčios klausimu. Atviras laiškas p. A. Jakštui [On the Resurrection Church. Open letter to A. Jakštas]", Rytas [The morning] (29 April 1929), 2-3.

40 Adomas Jakštas, "Atviras atsakymas p. B. Sruogai [Open answer to B. Sruoga]", Rytas [The morning] (29 April 1929), 4-5.

${ }_{41}$ S. Laucius, "Dèl prisikèlimo bažnyčios [On the Ressurection Church], “ Šiaurés Lietuva [Northern Lithuania] (27 June 1930), 2.

42 "Ar atgimsta architektūra? [Is architecture being reborn?]“, Židinys [Fireplace] 2 (1935), 636.

43 Michailas Vorobjovas, "Architektūros dorovè [The morality of architecture]", Lietuvos aidas [Echoes of Lithuania] (5 September 1939), 4. 
44 Halina Kairiūkštytè-Jacynienè, “Dèl Vytauto Didžiojo vardo muziejaus projekto [On the project for Vytautas Magnus museum]“, Židinys [Fireplace] 8-9 (1931), 167.

45 Getneris, Jurgis, "Kelios urbanistinès gairès „uosto“ kvartalui planuoti [Some urban guidelines for planning a "port" quarter]", Naujoji Romuva [New romuva] 39 (1938), 715.

46 Vytautas Landsbergis, "Urbanizmo klausimas Lietuvoje [On question of Urbanism in Lithuania]", Naujoji Romuva [New romuva] 4 (1936), 887.

47 "Bokštuotasis Kaunas [Kaunas of towers]", Lietuva [Lithuania] (4 January 1928), 4.
48 "Dar dèl Kauno statybos neplaningumo [More on unplanned construction of Kaunas]“, Naujoji romuva [New romuva] 25-26 (1939), 527.

49 Jonas Kovalskis-Kova, "Kauno miesto tvarkymas", Naujoji romuva [New romuva] 47 (1937), 875.

50 "Laikraščių iškarpos kuriose rašoma apie muziejų [Newspaper clippings about the museum]“, 1938, Lithuanian Central State Archives, f. 1764, ap. 1, b. 279, 1. 3.

51 Blair Kamin, "Architecture Criticism: Dead of Alive?", Nieman Reports (July 16, 2015), https://niemanreports. org/articles/architecture-criticism-dead-or-alive/.

Vaidas PETRULIS

KTU Architektūros ir statybos institutas, Kaunas, Lietuva

\section{ARCHITEKTŪROS KRITIKA TARPUKARIO LIETUVOS SPAUDOJE: REIŠKINIO PRIELAIDOS}

Santrauka

Pagrindinis šio straipsnio tikslas - išsiaiškinti, ar tarpukario Lietuvos (1918-1940) viešajame kalbejjime susiformavo specifinis architektūros kritikos žanras, ir jeigu taip, apibrèžti pagrindines šio reiškinio tendencijas. Architektūros kritiką apibrěžus kaip viešajj kalbejjimą, kuriame remiantis teorinėmis žiniomis populiariai pristatomi svarstymai apie architektūros esmę arba vykstančios miesto raidos bei pastatų vertinimai, straipsnyje aptariami tokio pobūdžio tekstai tarpukario Lietuvoje. Publikacija skaitytojus supažindins su kūrybingiausiais architektūros apžvalgininkais ir architektūros kritikai priskiriamų publikacijų tematine įvairove, atskleis personalizuotus, netikètus, šiuo metu paveldo objektais jau tapusių pastatų vertinimus.

Reikšminiai žodžiai: architektūros kritika, modernizmas, tautinis stilius, architektūrinis švietimas, tarpukario Lietuva.

$\mathrm{PhD}$ Vaidas Petrulis is a senior researcher in the Institute of Architecture and Construction at the Kaunas University of Technology. Co-author of books Architecture in Soviet Lithuania (2012), Architectural Heritage of the Interwar Period in Lithuania: The Combination of Tangibility and Intangibility (2015).

Author of the monograph Heritage as a Conflict: the Shift Between Modernist and After-Modernist Concepts of Heritage in Lithuania (2019). Since 2009 developed a digital internet archive of architectural heritage (www.autc.lt). Member of ISC20C (the International Scientific Committee for the $20^{\text {th }}$ Century Heritage of ICOMOS), member and chair (since 2018) of Working Group on the $20^{\text {th }}$ Century Built Heritage within the framework of the Baltic Region Heritage Committee.

E-mail: vaidas.petrulis@ktu.lt 